\title{
Importance of prophylactic veterinary measures in public health
}

\author{
Mateusz Grajek', Joanna Woźniak-Holecka² \\ 1 Zakład Technologii i Oceny Jakości Żywności Katedra Dietetyki, Śląski Uniwersytet Medyczny w Katowicach \\ 2 Zakład Promocji Zdrowia Katedry Dietetyki Wydział Zdrowia Publicznego Śląski Uniwersytet Medyczny w Katowicach
}

Grajek M, Woźniak-Holecka J. Importance of prophylactic veterinary measures in public health. Med Og Nauk Zdr. 2014; 20(4): 347-350. doi: 10.5604/20834543.1132033

\section{Abstract}

Introduction. Activities within the scope of veterinary treatment are commonly associated with help for animals in the vicinity of man, and free living animals. It is frequently forgotten that veterinary medicine covers also qualified activities in the service of public health. People should be aware that veterinary measures (vaccinations, deworming, protection against insects) are a form of health care not only for animals but also for humans.

Objective. The objective of the study was an analysis of awareness among dog owners concerning health risks resulting from having a dog at home, and observance of prophylactic veterinary procedures.

Material and methods. During the period 1 November 2011-29 February 2012, a survey was conducted which covered 300 dog owners from urban areas. The information collected by means of a questionnaire were subjected to statistical analysis using software Statistica 10 . The non-parametric chi-square test was applied $(p=0.05)$ for qualitative characteristics, with V Cramer's coefficient to assess dependence.

Results. The results obtained showed that females, more frequently than males, are concerned about the health of their dogs. Nearly $78 \%$ of respondents vaccinate their dog against rabies once a year, $61 \%$ - deworm their dog at least twice a year, and less than $4 / 5$ of the respondents protect their dog against eco-parasites.

Conclusion. The study showed that prophylactic veterinary procedures are a generally accepted and common form of zoonoses control; however, despite this fact, there is a need for the constant education of society in order to prevent diseases transmitted by domestic dogs.

\section{Key words}

veterinary public health, prevention of diseases, zoonoses, dogs

\section{INTRODUCTION AND OBJECTIVES}

Speaking of health as a complete well-being, both physical and psychosocial, should be remembered the multidimensionality of the concept and the factors that affect them [1]. Already in the eighteenth century Austrian physician Johann Peter Frank, the author of a work entitled "System einer vollständigen medizinischen Polizey”, defined the public health as overall measures to protect human health and the health of animals that accompany him [2].

The activities from the area of veterinary treatments are associated with helping animals from the vicinity of humans and wild animals. It is often forgotten that veterinary consists also of qualified veterinary actions in the service of public health. At the same time the impact of animal health on human health is often forgotten, and measures such as vaccination against rabies, deworming, etc. taken as help for domesticated and wild living animals Meanwhile, such actions serve not only to animal health but also protection of people against the possibility of contracting life-threatening diseases.

Dogs are the most numerous and most widespread carnivores, and their total number depends on the size of human population and increases with it. More than $62 \%$ of U.S. households have a pet $[3,4]$, and in Europe in more than $50 \%$ of households lives a dog [5]. The approximate number

Adres do korespondencji: Joanna Woźniak-Holecka, Zakład Promocji Zdrowia Katedry Dietetyki, Wydział Zdrowia Publicznego, Śląski Uniwersytet Medyczny w Katowicach, ul. H. Jordana 19, 41-808 Zabrze

E-mail: jwozniak@sum.edu.pl

Nadesłano: 5 listopada 2013 roku; Zaakceptowano do druku: 28 lipca 2014 roku of dogs in Poland is similar to the human population and amounts about 40 million, of which about 70 thousand dogs are stray [6].

Dogs are involuntary carriers of the pathogens, including viruses, bacteria, fungi and parasites. Pathogens are accidentally transmitted to people directly - through close contact, indirectly - through pollution or so-called. vectors. Some of these infections, such as rabies, echinococcosis and leptospirosis are widespread and result in significant health problems $[7,8]$. Especially in urban areas the dogs are an important public health problem. In most developing countries, the number of stray dogs usually exceeds the number of dogs with owners.

The aim of this study was to analyze the awareness of dog owners on the health risks of having a domestic dog and the observance of veterinary preventive procedures. The essence of this study was the assumption that people with dogs have a low awareness and do not apply to generally accepted standards and principles of prevention.

\section{MATERIALS AND METHODS}

In the period between 01.11.2011-29.02.2012 were conducted anonymous survey based on the author's questionnaire survey addressed to people owning dogs. The group of respondents was composed of clients of veterinary clinics and pet shops, being a dog owners.

The questionnaire consisted of questions designed to assess the awareness of respondents about the knowledge of preventive veterinary procedures and their implementation. 
The researched group consisted of 300 dog owners living in urban areas. The criteria, which were adopted for people the participating in the study assumed owning least one domestic dog, legal age (age $18+$ ), the declaration of residence in an urban area, and lack of education related to the researched topic.

The information gained from the questionnaires were subjected to statistical analysis in the Statistica 10 environment. Was used a nonparametric chi-square test $(\mathrm{p}=0.05)$ for the qualitative characteristics with V-Cramér coefficient.

\section{RESULTS}

The group of respondents was dominated by female sex $62.0 \%$ of population, men constituted $38.0 \%$ of the population under research, people above 30 years of age were a prevailing percentage of the population $(68,0 \%)$ than people between $18-29$ years old (32,0\%). Dog owners usually were legitimizing with a secondary education (55.0\% of population), other respondents declared professional and higher education (respectively $22.5 \%$ of population).

First, the respondents were asked how often they vaccinate their dogs against rabies. The majority of respondents (77.7\%) vaccinates dogs once a year. However, $11.0 \%$ of population are doing it less often, and $11.3 \%$ doesn't subject dogs to vaccination. More women (85.0\%) than men (65.8\%) vaccinates dogs every year. More men (13.2\%) admits that they are doing it less often than once a year, comparing to women - only $9.7 \%$ of respondents. As many as $21.1 \%$ of men are not subjecting their dogs at all, it is the value of almost four times higher than for women (5.4\%). In addition, young people (18-29 years) vaccinate dogs against rabies 1.5 times more likely than older people (over 30 years)what has been confirmed by a statistical test $\left(\chi^{2}=17.93659 \mathrm{~V}=0.24511\right.$, $\mathrm{p}=0.00013$ ) (Fig. 1).

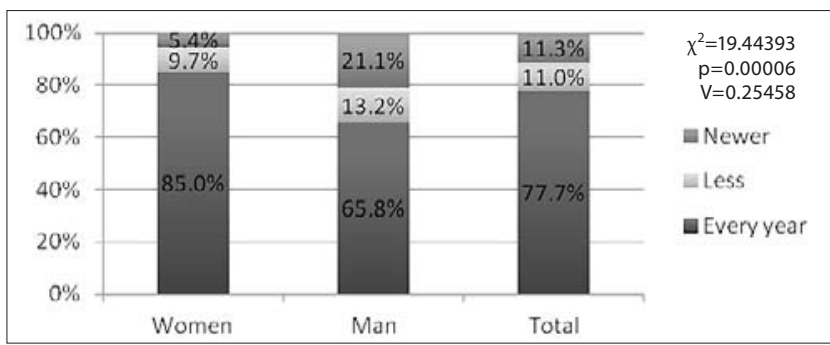

Figure 1. Dogs vaccination dynamics against rabies $(n=300)$. Source: own studies

In this part of the survey respondents were asked, whether they vaccinate their dog against other zoonosis. $77.0 \%$ of respondents did not opt for additional voluntary vaccination of a dog or did not cope with the response to such question pointing out the possibility of infection from the dog with diseases that are not an antropozoonosis (eg. distemper, parovirosis, Lyme disease, kennel cough) - 20\%. Only $3.0 \%$ of population said they had the dog additionally vaccinated against leptospirosis.

More than half of the respondents (61.0\%) deworms their dogs twice a year. Only $8.0 \%$ of respondents declares that they never dewormed their dogs, $10.0 \%$ does it once a year, and $21.0 \%$ more often than twice a year (Fig. 2). No significant differences were detected in deworming dogs by men and women (13.2\% vs. $4,8 \%)$. About $21.0 \%$ of men and women admit they deworm the dog more often than twice a year. The applied statistical test showed a dependence, that women more often pay attention to dog deworming $\left(\chi^{2}=24,75502\right.$; $\mathrm{p}=0,00002 ; \mathrm{V}=0,28726)$. No correlation with the age of respondents was detected.

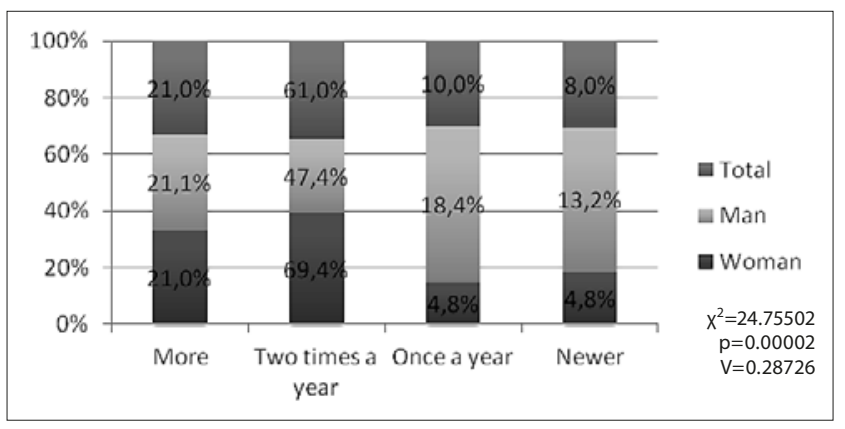

Figure 2. The level of dog deworming performed by owners $(n=300)$. Source: Ibidem

The study showed that $65 \%$ of respondents protects dog against this type of insect (fleas and ticks) seasonally - from spring to autumn, $14 \%$ secures also after the season, and $21 \%$ not at all. The vast majority of the women compared to men (77.4\% vs. $44,7 \%)$ protects dogs against external parasites seasonally. After the season dogs are properly secured by $16.1 \%$ women and $10.5 \%$ of men. Only $6.5 \%$ of women admit that they do not protect their dogs at all, for men it is $44.7 \%$ (Fig. 3). No correlated dependency with age of the respondents was detected.

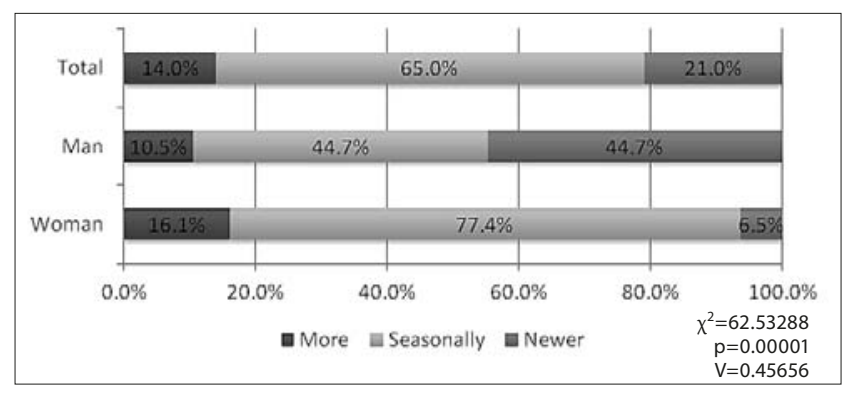

Figure 3. The dynamics of protection of dogs against ectoparasites by respondents $(n=300)$. Source: Ibidem

One of the questions from the questionnaire related to the incidence of zoonotic diseases among the examined population. This question was answered positively by 54 people, what represents $9.0 \%$ of the studied population. According to the respondents, they or their loved ones, after contacts with dogs contracted a fungal infection (65.0\%).

At the end the respondents were asked whether they are informed by the staff of the health risks stemming from having the animals. $80.5 \%$ of respondents in response recognize that they receive comprehensive answers to their questions from their veterinarian, as well as advice and guidance in order to avoid zoonotic diseases.

\section{DISCUSSION}

The research carried out in the framework of the study is a pioneering project and marks a new trend, especially in the 
field of public health. The study addresses topics of diseases transmitted by dogs dogs, because they are the most common pet in urban areas.

A disease transmitted by dogs, which undoubtedly focuses the most attention of epidemiologists is rabies. This disease occurs almost all over the world (countries where rabies is considered to be absent are: Australia, Belgium, Chile, Czech Republic, Greece, Greenland, Ireland, Iceland, Japan, Nicaragua, New Zealand, Norway, Malaysia, Sweden, Switzerland, Panama, Portugal and Uruguay) $[8,9]$. Generally, the WHO estimates, that each year die from this disease approximately 55 thousand people (150 cases per day), up to $40 \%$ of them are children under 15 years of age [10]. In Poland since 1985 there were only two cases of the disease (2000 and 2002) [11], one of which ended with death. That is why, from the point of view of public health, the disease is very important, especially since the only rescue is a mass vaccination of animals (eg vaccination of dogs and foxes) and pre- and post-exposure actions to specific risk groups and people that were bitten by a suspected animal [12]. Polish legal norms dictate the need for annual dog vaccination [13], according to the own research only about $78 \%$ of dog owners apply to this provision.

More than $80 \%$ of the U.S. population does not combine the risk of contracting a invasive disease with dog feces. Many pet owners are unaware that nematodes and hookworms pose a serious threat to the health of their animals, as well as for the whole family. The best way to reduce the prevalence of parasitic invasion is constant veterinary care. Animals that are routinely dewormed not do excrete infected feces, which is especially important for dog owners with children [14]. From the own research results that respondents from the Silesian area are very responsible $-92 \%$ of dog owners are at least once a year deworming their dog.

In the period from spring to autumn dogs should be protected against ectoparasites, such as: ticks, mites and demodex, fleas, lice and mallophaga and tachnid flies. Forms of protection include: removing ticks using special protective gloves, tweezers (forceps) and tick twisters, because there is a possibility of infection through skin contact [15], seasonal use of repellents or insecticides, also it is important to regularly check your skin and the early detection of possible infection in aim to apply the correct medication [16]. On the other hand when it comes to fleas they often mediate in the development cycle of the dog tapeworm. Larval stage of the tapeworm places in the body cavity of flea. The invasion in dogs occurs by eating an adult flea while tries of gnawing. Sometimes it happens that an infected flea is ingested by humans, who becomes an accidental host for the parasite. This applies especially to children, who rarely follow the rules of hygiene in the relationship with animals [17].

\section{CONCLUSIONS}

1. Veterinary treatments are a generally acceptable and common form of combating zoonoses. The respondents have a high awareness in the field of preventive veterinary actions. In particular, respondents are aware of their responsibilities in relation to the protection of public health with proper preventive measures.

2. A small number of people can correctly identify zoonoses. This fact points to the need for extensive promotional and educational activities referring to the issues of this study.

3. The veterinary staff is aware of the seriousness of their role in maintaining the health of the population and informs their customers how to avoid the health risks of zoonotic diseases.

\section{REFERENCES}

1. Kiedlik D, Fal A. Podstawy zdrowia publicznego. W: Felińczak A, Fal A (red.). Zdrowie publiczne. Wrocław: Akademia Medyczna im. Piastów Śląskich; 2010: 9-11.

2. Opolski J. Zdrowie publiczne. Wybrane zagadnienia, t. 1. Warszawa: Szkoła Zdrowia Publicznego CMPK; 2011.

3. Macpherson C, Meslin F, Wandeler A. Dog, Zoonoses and Public Health. New York: CABI Publishing; 2000.

4. Reader's Digest Eurodata - a Consumer Survey of 17 European Countries, Reader's Digest Association, London, 1991.

5.2011-2012 National Pet Owners Survey. American Pet Products Association, Greenwich, 2011.

6.http://www.mysafeanimal.pl/statystyki/12-liczba-bezdomnych-psowi-kotow-w-polsce.html (dostęp: 2012.02.01).

7.WHO Technical Report Series: WHO expert consultation on rabies. Geneva: WHO Library Cataloguing-in-Publication Data; 2004.

8. Kłapeć T, Cholewa A. Zagrożenia dla zdrowia związane ze stosowaniem nawozów organicznych i organiczno-mineralnych. Medycyna Ogólna i Nauki o Zdrowiu, 2012; 18(2): 131-136.

9. Lis H, Górski K. Ocena sytuacji epizootiologicznej wścieklizny na terenie Europy w 2011 r. Życie Weterynaryjne, 2013; 88(4): 309-312.

10.http://www.who.int/mediacentre/factsheets/fs099/en/ (dostęp: 2011.05.01).

11. Narodowy Instytut Zdrowia Publicznego: Państwowy Zakład Higieny, Zakład Epidemiologii, Pracownia Monitorowania i Analizy Sytuacji Epidemiologicznej, Meldunki roczne, na: http://www.pzh.gov.pl/ oldpage/epimeld/index_p.html (dostęp: 2011.05.01).

12. Mrożek-Budzyn D. Wakcynologia praktyczna. a-medica press, Kraków; 2009.

13. Ustawa $z$ dn. 11. marca 2004 r. o ochronie zdrowia zwierząt oraz zwalczaniu chorób zakaźnych zwierząt (Dz. U. 2004 Nr 69 poz. 625).

14. http://www.prnewswire.com/news-releases/is-your-city-in-the-doghouse-56088532.html (dostęp: 2012.05.01).

15. Frymus T. Choroby zakaźne psów. Warszawa: Si-ma; 1999.

16. Maciołek H. Epidemiologia chorób odzwierzęcych w zarysie. Akademia Świętokrzyska im. Jana Kochanowskiego w Kielcach, Piotrków Trybunalski, 2001.

17. Blagburn B. Tapeworm - overlooked, underdiagnosed and undertreated. Alabama: Virbac Animal Health; 2006. 


\title{
Znaczenie profilaktycznych zabiegów weterynaryjnych w zdrowiu publicznym
}

\author{
I Streszczenie \\ Wstęp. Działania z zakresu lecznictwa weterynaryjnego kojarzą się powszechnie z pomocą zwierzętom z bliskiego otoczenia \\ człowieka oraz zwierzętom wolno żyjącym. Zapomina się niejednokrotnie, że weterynaria to również profesjonalne działania \\ stojące w służbie ochrony zdrowia publicznego. Należy zadawać sobie sprawę, że zabiegi weterynaryjne (szczepienia, \\ odrobaczanie, zabezpieczanie przeciw insektom) stanowią formę ochrony zdrowia nie tylko zwierząt, ale także ludzi. \\ Cel pracy. Celem pracy była analiza świadomości właścicieli psów w zakresie zagrożeń zdrowia wynikających z posiadania \\ psa domowego oraz przestrzegania weterynaryjnych zabiegów profilaktycznych. \\ Materiał i metody. W okresie 01.11.2011-29.02.2012 przeprowadzono badanie ankietowe obejmujące 300 właścicieli psów \\ z terenów miejskich. Informacje pozyskane z ankiet poddane zostały analizie statystycznej w środowisku Statistica 10. \\ Wykorzystano nieparametryczny test chi-kwadrat $(\mathrm{p}=0,05)$ dla cech jakościowych ze współczynnikiem zależności V-Cramér'a. \\ Wyniki. Otrzymane zależności wykazują, że to częściej kobiety, w porównaniu do mężczyzn, troszczą się o zdrowie swoich \\ psów. Blisko 78\% respondentów szczepi psa corocznie przeciw wściekliźnie, $61 \%$ odrobacza psa przynajmniej dwa razy do \\ roku, a niespełna $4 / 5$ badanej populacji chroni psy przed ektopasożytami. \\ Wnioski. Z przeprowadzonych badań wynika, że weterynaryjne zabiegi profilaktyczne są ogólnie akceptowaną i powszechną \\ formą walki z chorobami odzwierzęcymi, mimo to istnieje konieczność ciągłej edukacji społeczeństwa w celu zapobiegania \\ chorobom przenoszonym przez psy domowe.
}

\section{Słowa kluczowe}

weterynaryjne zdrowie publiczne, profilaktyka chorób, choroby odzwierzęce, psy 